\title{
Chemical defense in the red seaweed Plocamium brasiliense: spatial variability and differential action on herbivores
}

\author{
Pereira, $R C .{ }^{a *}$ and Vasconcelos, $M A .^{a}$ \\ a Departamento de Biologia Marinha, Instituto de Biologia, Universidade Federal Fluminense - UFF, \\ Morro do Valonguinho, s/n, Centro, CP 100.644, CEP 24001-970, Niterói, RJ, Brazil \\ *e-mail: rcrespo@id.uff.br
}

Received: June 19, 2012 - Accepted: April 22, 2013 - Distributed: August 31, 2014

(With 4 figures)

\begin{abstract}
Species of Plocamium are known as prolific sources of halogenated secondary metabolites exhibiting few explored ecological roles. In this study the crude extracts from specimens of $P$. brasiliense collected in two distinct places, Enseada do Forno and Praia Rasa, Búzios, Estado do Rio de Janeiro, were evaluated as defense against the sea urchin Lytechinus variegatus and the crab Acanthonyx scutiformis. These specimens produce a similar amount of crude extract and also halogenated monoterpene compound-types, but individuals of $P$. brasiliense from Praia Rasa exhibit a major compound representing about $59 \%$ of the total chemicals. Natural concentrations of the crude extracts obtained from both specimens of $P$. brasiliense significantly inhibited the herbivory by the sea urchin $L$. variegatus, but had no significant effect on the feeding by $A$. scutiformis, a crab commonly associated to chemically defended host. Crude extract from $P$. brasiliense collected at Praia Rasa was more efficient as defense against $L$. variegatus than that crude extract from populations of this alga from Enseada do Forno, probably due to presence of a major secondary metabolite. These two studied population live under different environmental conditions, but they are only about $30 \mathrm{Km}$ apart. However, it is impossible to affirm that environmental characteristics (abiotic or biotic) would be responsible for the difference of defensive potential found in the two populations of $P$. brasiliense studied here. Further genetic studies will be necessary to clarify this question and to explain why populations of a single species living in different but close locations can exhibit distinct chemicals.
\end{abstract}

Keywords: chemical defense, Plocamium brasiliense, herbivory, spatial variability.

\section{Defesa química na macroalga marinha vermelha Plocamium brasiliense: variabilidade espacial e diferentes ações sobre herbívoros}

\begin{abstract}
Resumo
Espécies de Plocamium são conhecidas como fontes prolíficas de metabólitos secundários halogenados com significados ecológicos pouco conhecidos. Neste trabalho extratos brutos de espécimes de $P$. brasiliense coletados em duas localidades distintas, Enseada do Forno e Praia Rasa, Búzios, Estado do Rio de Janeiro, foram avaliados como defesa química contra o ouriço Lytechinus variegatus e o caranguejo Acanthonyx scutiformis. Estes espécimes produzem teores similares de extrato bruto e tipos de substâncias monoterpenos halogenados, mas os indivíduos da Praia Rasa possui um componente majoritário representando $59 \%$ do total de metabólitos. Concentrações naturais dos extratos brutos destes espécimes inibiram significativamente o consumo por $L$. variegatus, mas não causaram qualquer efeito sobre $A$. scutiformis, um caranguejo comumente associado a $P$. brasiliense, um hospedeiro quimicamente defendido. $\mathrm{O}$ extrato bruto de $P$. brasiliense coletada na Praia Rasa foi mais eficiente como defesa frente a $L$. variegatus do que aquele obtido de população desta alga da Enseada do Forno, provavelmente pela presença de uma substância majoritária. Estas duas populações de $P$. brasiliense estudadas vivem sob diferentes condições ambientais, mas distantes somente cerca de $30 \mathrm{~km}$. Entretanto, é impossível afirmar que características ambientais (abióticas ou bióticas) seriam responsáveis pelas diferenças de potencial defensivo encontrados nestas duas populações de $P$. brasiliense estudadas. Futuros estudos genéticos são necessários para esclarecer esta questão e para explicar porque populações de uma mesma espécie vivendo em regiões tão próximas, mas ambientalmente distintas, produzem substâncias distintas.
\end{abstract}

Palavras-chave: defesa química, Plocamium brasiliense, herbivoria, variabilidade espacial. 


\section{Introduction}

Chemical defenses of macroalgae have been extensively investigated during last 20 years, encompassing since species from Antarctic polar waters (Amsler et al., 2008) to those from the tropics (Pereira and Da Gama, 2008), and including several species of green, brown, and red ones. In fact, several species of macroalgae have the capacity to produce secondary metabolites, which exhibit important and vital ecological roles as defense and/or signal compounds (Amsler, 2008).

Green macroalgae, mainly species of Bryopsidales are abundant and widely distributed in tropical seas, and known to produce mainly sesquiterpenoid and diterpenoid compounds (Blunt et al., 2009, and previous reviews of this author). Some of these metabolites have been implicated in well documented studies that evidenced its property as a chemical defense against grazing by several species of fishes (Hay et al., 1990; Wylie and Paul, 1988), and invertebrates such as gastropods (Davis et al., 2005), mollusk (Pennings and Paul, 1992), and sea urchins (Hay et al., 1994; Lima et al., 2008).

Brown macroalgae produce terpenoids, acetogenins, and terpenoid-aromatic compounds of mixed biosynthetic origin as their most common secondary metabolites (Blunt et al., 2012, 2011, 2010). In addition, brown macroalgae also produce polyphenols (= phlorotannins), but mainly in higher concentrations in species from temperate (Toth and Pavia, 2006) and polar regions (Fairhead et al., 2006). Among brown algae, Dictyota species were the most studied species and they are known to produce chemicals capable of inhibiting fishes (Cronin et al., 1997), sea urchin (Barbosa et al., 2004), gastropod (Pereira et al., 2002), crab (Pereira et al., 2000b), and amphipod (Pereira et al., 2000a).

Red species are the richest between other macroalgae in terms of secondary metabolite diversity and abundance (Blunt et al., 2009, and previous reviews of this author), encompassing more than 1500 different compounds belonging to all major classes of natural products (Maschek and Baker, 2008). Among these chemicals, isoprenoid and acetogenin derivatives are recognised as the primary class of defensive metabolites in these algae (Harper et al., 2001). In addition, red macroalgae are also characterised by the production of an impressive array of halogenated compounds exhibiting defensive properties against herbivory (Pereira and Da Gama, 2008).

Macroalgae secondary metabolites that deter herbivory can be qualitatively or quantitatively variable, but the intraspecific patterns of qualitative or quantitative variation in these chemicals are largely undocumented (but see Van Alstyne et al., 1989), and thus underappreciated in marine organisms. Due to the known broad ecological roles of macroalgae secondary metabolites (Hay and Fenical, 1988; Cronin, 2001; Paul et al., 2001), these variations may be of significant importance and/or have repercussions for population and community structure.

For example, terpenoid compounds in macroalgae occur in relatively low concentrations, ranging from $0.2 \%$ to $2.0 \%$ of algal dry mass (Paul and Fenical, 1986, 1987). However, the variation in secondary metabolites content or compound-type may occur at a number of different levels: among individuals within a population (Sudatti et al., 2006) or among populations of the same species growing in different habitats (Pereira et al., 2000a, 2004).

Species of Plocamium have been shown to be a rich source of terpenoids that vary for a given species depending on collection and season (Naylor et al., 1983). For example, different chemicals were verified in specimens of $P$. cartilagineum and $P$. violaceum, probably due to individual enzymatic processes (Mynderse and Faulkner, 1978). High chemical and diversity variability were also verified in major compounds of different populations of $P$. violaceum from California (Crews and Kho-Wiseman, 1977). Differences between specimens of different populations of $P$. violaceum (Faulkner, 1977) and P. cartilaginum (Higgs et al., 1977) were sufficient to propose the existence of chemotypes of these species along the littoral of California. Chemotypes of $P$. cartilagineum and $P$. hamatum were also verified along the littoral of Chile (San-Martin and Rovirosa, 1986; Rovirosa et al., 1988) and Australia (Coll et al., 1988; Konig et al., 1990), respectively.

In fact, a large variety of secondary metabolites has been isolated from Plocamium species from Antarctic (e.g. Rovirosa et al., 1990) to tropical regions (Capon et al., 1984), but very few studies have explored the potential ecological roles of these compounds and their contents. However, previous studies evidenced that chemicals from $P$. lepitophyllum and P. cartilagineum inhibit consumption by sea-urchin and gastropods (Sakata et al., 2000) and amphipod (Ankisetty et al., 2004). In addition, superficial chemicals from $P$. hamatum act as allelopathic in competitive interaction with coral (De Nys et al., 1991).

In order to ascertain the spatial variability in defensive chemicals among Brazilian populations of Plocamium brasiliense, the crude organic extracts and major secondary metabolites from two populations of this seaweed were investigated to specifically answer the following questions: 1) Is there quali-/quantitative variation in $P$. brasiliense secondary metabolites in two close but different places on the Brazilian littoral? 2) Do these metabolites play a defensive role against consumers? 3) Does metabolite variation impact herbivore defense of $P$. brasiliense in different places?

\section{Material and Methods}

\subsection{Organisms}

Specimens of the red macroalga $P$. brasiliense were collected off the Brazilian coast - Enseada do Forno $\left(22^{\circ}\right.$ $\left.45^{\prime} \mathrm{S}, 41^{\circ} 52^{\prime} \mathrm{W}\right)$ and Praia Rasa (22 $44^{\prime} 10 \mathrm{~S}, 42^{\circ} 57^{\prime}$ $50 \mathrm{~W}$ ), Búzios, Rio de Janeiro State, at depths ranging from 0.5 to $3.5 \mathrm{~m}$ in November, 2005. After being collected, these algal specimens were transported to the laboratory in ice cases, and then gently washed in seawater to eliminate macroscopic associated epibiota, as well as microorganisms loosely attached on its thalli. Voucher specimens were 
deposited in the Herbarium of the Universidade do Estado do Rio de Janeiro (HRJ 10331-32).

Specimens of the sea urchin Lytechinus variegatus used in assays were collected in the sublittoral region at Itaipu Beach (Niterói, RJ - Brazil), while individuals of Acanthonyx scutiformis were collected at Praia Rasa (Búzios, $\mathrm{RJ}$ - Brazil). In the laboratory all these individuals were maintained in containers with seawater, where they were kept in a recirculating laboratory aquarium at constant temperature $\left(20^{\circ} \mathrm{C}\right)$, salinity $(35)$ and aeration during the acclimation period, during which Ulva sp. was offered as food, before the assays.

\subsection{Chemical procedures}

The air-dried algae from Praia Rasa (423 g) and Enseada do Forno (240 g) were successively extracted with $\mathrm{CH}_{2} \mathrm{Cl}_{2}$ at room temperature $\left(25^{\circ} \mathrm{C}\right)$, in an ultra-sound apparatus ( $3 \times 1.0 \mathrm{~L}$ for $3 \mathrm{~min})$. The solvent was evaporated under reduced pressure yielding a yellowish residue (2.5 and 1.6 $\mathrm{g}$, respectively), both used in feeding assays and also to analyse the chemical profiles. TLC of the extracts were performed on Merck Kieselgel $\mathrm{GF}_{254}(0.2 \mathrm{~mm})$ precoated aluminum plates and spots were observed under UV light $(254 \mathrm{~nm})$ and visualised by spraying with a $2 \%$ ceric sulphate in sulfuric acid, followed by heating at $100{ }^{\circ} \mathrm{C}$. Silica gel 60 (Merck, 70-230 and 230-400 mesh) were used for column chromatography.

The extracts were analysed by HRGC-MS (gas chromatographic analysis) on a HP 6890 series GC system, coupled to a HP 5973 mass selective detector in the electron impact mode $(70 \mathrm{eV})$ equipped with an HP-1 MS capillary column ( $30 \mathrm{~m} \times 0.25 \mathrm{~mm}$; film thickness $0.25 \mu \mathrm{m})$. Injector and detector temperatures were set at $270{ }^{\circ} \mathrm{C}$ and $290^{\circ} \mathrm{C}$, respectively. The temperature program was kept at $60{ }^{\circ} \mathrm{C}$, then programmed to $290{ }^{\circ} \mathrm{C}$ at a rate of $10^{\circ} \mathrm{C} / \mathrm{min}$ for $15 \mathrm{~min}$. Hydrogen was the carrier gas at a flow rate of $1 \mathrm{~mL} / \mathrm{min}$. Diluted samples were injected manually in the split mode (1:10). Data were obtained from Frd area percent values. The chemical components were identified based on mass spectral comparison with those of standards and/or literature data, by co-injection in HRGC of these samples and from the Wiley 275 library data of the HRGC-MS system.

\subsection{Feeding Experiments}

The defensive property of the crude extracts and the major compound found in P. brasiliense, faced with the sea urchins Lytechinus variegatus and Acanthonyx scutiformis, were verified by including natural concentrations of each one of the components separately in an artificial food (Hay et al., 1994; Pereira et al., 2000b). The food (control) was prepared by adding $0.72 \mathrm{~g}$ of agar to $20.0 \mathrm{ml}$ of distilled water and heating it in a microwave oven until boiling point. This mixture was added to $16.0 \mathrm{ml}$ of cold water containing $2.0 \mathrm{~g}$ of the freeze-dried green seaweed Ulva spp. The experimental food (treatment) was similarly prepared, but the crude extract or pure compound of $P$. brasiliense was first dissolved in diethyl ether, added to $2.0 \mathrm{~g}$ of freeze- dried Ulva, and the solvent was then removed by rotary evaporation. This procedure is necessary to obtain a uniform coating of natural products on the algal particles prior to their addition to the agar (Hay et al., 1994). Treatments and controls were hardened onto a screen and cut into small pieces ( $7 \times 10$ squares about $1.2 \times 1.4 \mathrm{~mm}$ each), which were then simultaneously offered to the sea urchin L. variegatus, in small plastic containers, each containing $250 \mathrm{ml}$ of seawater ( $\mathrm{n}=18$ to 22 replicates; see "Results").

Wilcoxon matched pairs test, a nonparametric equivalent to the $t$-test, was used to evaluate the statistical significance of the results obtained in the feeding assays.

\section{Results and Discussion}

Similar percentages of total crude extracts were obtained from specimens of $P$. brasiliense collected at Praia Rasa and Enseada do Forno (Table 1). In addition, the CCD, UV and HRGC-MS analysis confirmed that these specimens also produce similar compounds or exhibit the same or a very similar chemical profile (Figure 1). However, the extract of $P$. brasiliense from Praia Rasa showed a major compound representing about $59 \%$ of the total chemicals. In fact, a recent study revealed that both these populations of $P$. brasiliense produce halogenated monoterpenes, but while specimens from Praia Rasa showed only one halogenated monoterpene as major metabolite, individuals from Enseada do Forno exhibited several of these compound-types (Vasconcelos et al., 2010). These results confirm the ability of $P$. brasiliense to synthesise linear chlorinated and brominated monoterpenes, and also that Plocamium species produce variable contents of secondary metabolites depending on the collection location as previously observed worldwide (e.g. Crews et al., 1977; Mynderse and Faulkner, 1978; San-Martin and Rovirosa, 1986; Konig et al., 1990).

Natural concentrations of the crude extracts obtained from specimens of $P$. brasiliense from Enseada do Forno and Praia Rasa significantly inhibited herbivory by the sea urchin L. variegatus $(\mathrm{p}<0.05$, Wilcoxon paired-sample test, for both assays, Figure 2), confirming the predicted defensive property of the chemicals from this Brazilian red seaweed. These results also confirm previous evidence that Brazilian P. brasiliense was one of the last food items preferred by $L$. variegatus probably due to defensive chemicals produced by this macroalga (Souza et al., 2008). In general, chemicals from Plocamium species are very little explored in the context of its ecological roles, but it is known that crude extract of $P$. cartilagineum was significantly rejected by fish, sea star and amphipod

Table 1. Yield of crude extracts obtained from specimens of $P$. brasiliense collected in two distinct places, Praia Rasa and Enseada do Forno, Búzios, RJ, Brazil.

\begin{tabular}{lcc}
\hline $\begin{array}{c}\text { Collection of } \\
\boldsymbol{P} \text {. brasiliense }\end{array}$ & $\begin{array}{c}\text { Algal mass } \\
\text { extracted (g) }\end{array}$ & Yield (\%) \\
\hline Praia Rasa & 423.0 & 0.6 \\
Enseada do Forno & 240.0 & 0.7 \\
\hline
\end{tabular}




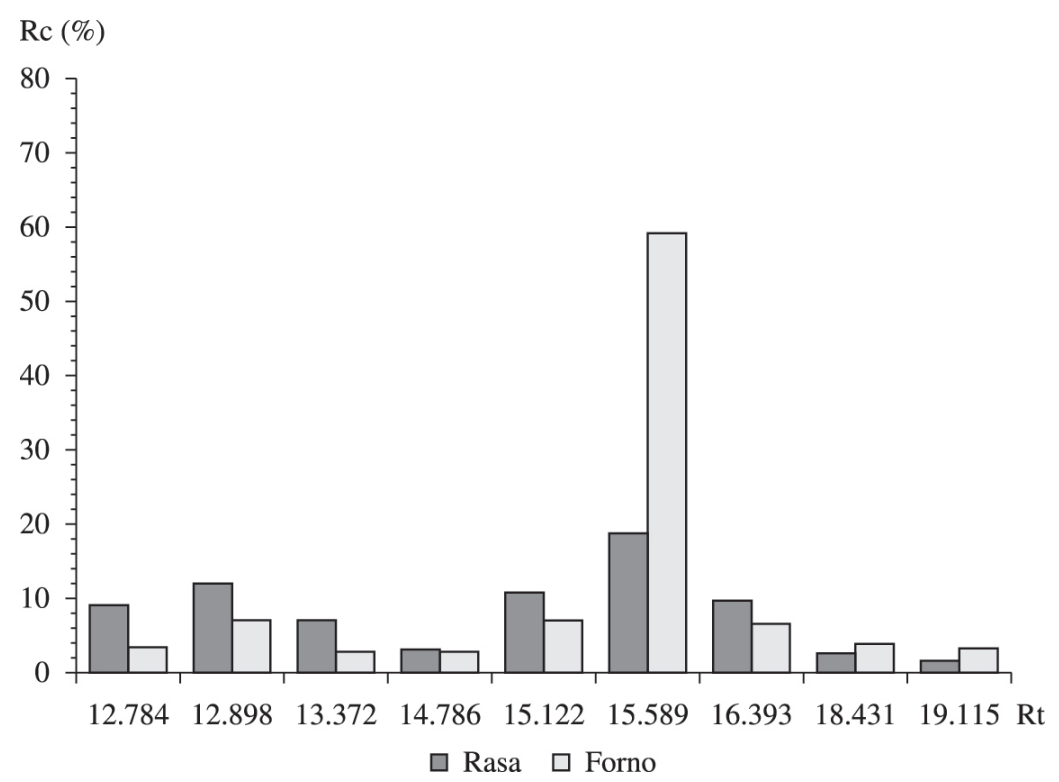

Figure 1. Relative abundance of compounds found in crude extracts from specimens of P. brasiliense from Praia Rasa and Praia do Forno.

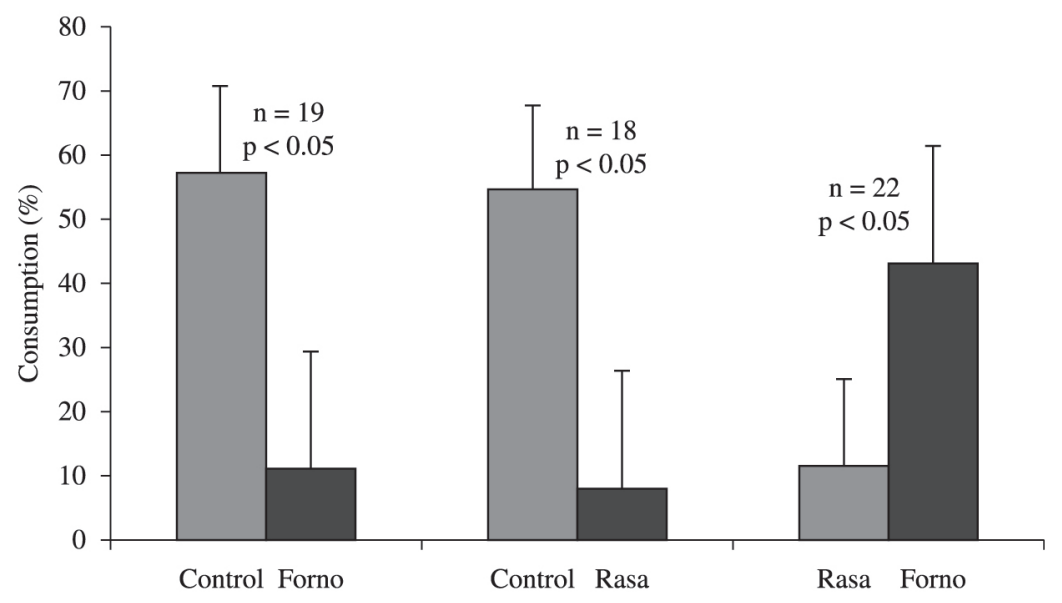

Figure 2. Effect of crude extracts from specimens of $P$. brasiliense collected at Praia Rasa and Forno on the consumption by the sea-urchin L. variegatus.

(Ankisetty et al., 2004), and benthic organisms living in close proximity to $P$. hamatum, including corals and sponges, exhibited several degrees of necrosis due to chemicals of this macroalga (De Nys et al., 1991).

In contrast to the patterns verified for L. variegatus, crude extracts from specimens of $P$. brasiliense from Enseada do Forno and Praia Rasa had no significant effect on feeding by the crab A. scutiformis (Figure 3). In fact, this crab is a generalist feeder, but it exhibits some preference by the chemically-defended P. brasiliense and also uses this macroalga as decoration and probably protection against predation (Vasconcelos et al., 2009). In fact, this is a typical mechanism exhibited by small and more specialised marine organisms that live associated to and consume the chemically defended host to minimise predation (Hay, 1992).

When both extracts were simultaneously offered to this sea urchin, the crude extract from $P$. brasiliense collected at Praia Rasa was more efficient as a defense against L. variegatus than the crude extract from populations of this alga from Enseada do Forno ( $p<0.05$, Wilcoxon pairedsample test, Figure 2). Similarly, crude extract and major secondary metabolites from the brown alga Stypopodium zonale from two different places on the Brazilian littoral significantly deterred feeding by consumers, although with distinct effectiveness (Pereira et al., 2004). In fact, despite the small differences in the yields observed in our extracts, we can stress that defensive chemicals 
from macroalgae are not qualitatively or quantitatively absolute or invariant characteristics of the species, and may represent an ecological specialisation to successfully prevent herbivory (Pereira et al., 2004).

The major compound (substance 1), from specimens of $P$. brasiliense from Praia Rasa, exhibited a defensive property against $L$. variegatus $(\mathrm{p}<0.05$, Wilcoxon pairedsample test, Figure 4), and the action of the crude extract against this sea-urchin (Figure 2) is probable due to this major compound. By contrast, oregonene A also found in these specimens, but in a smaller amount, was ineffective against this sea urchin $(p<0.05$, Wilcoxon paired-sample test, Figure 4).

In the marine environment, the knowledge of both the amount and variation in secondary metabolites is an essential element for assessing studies in chemical ecology and for placing them into an ecological and evolutionary context (de Nys et al., 1995, 1998). Here, we have shown that close populations of $P$. brasiliense exhibit different chemicals and these components exhibit distinct action against herbivory. However, what determines this difference?

In general, it is unclear whether variations in concentration and types of secondary metabolites result from herbivore-induced chemical defenses, local selection, genetic differences, or other factors not related to herbivores (Paul et al., 2001). Many marine macroalgae show extensive phenotypic variation, including the production of defensive chemicals which can be generated by variation in a number of known biotic-herbivore pressure (e.g. Cronin, 2001 for review) and abiotic factors (e.g. Sudatti et al., 2011).

The two studied populations live under different environmental conditions, but they are only about $30 \mathrm{Km}$ apart. Enseada do Forno is characterised by an environment under high wave energy, clear seawater, and subtidal dominance of the seaweeds Dictyota cervicornis Kuetzing, Sargassum furcatum Kuetzing, Stypopodium zonale (Phaeophyta) and Plocamium brasiliense (Greville) Howe et Taylor (Rhodophyta), and the sea urchins Echinometra

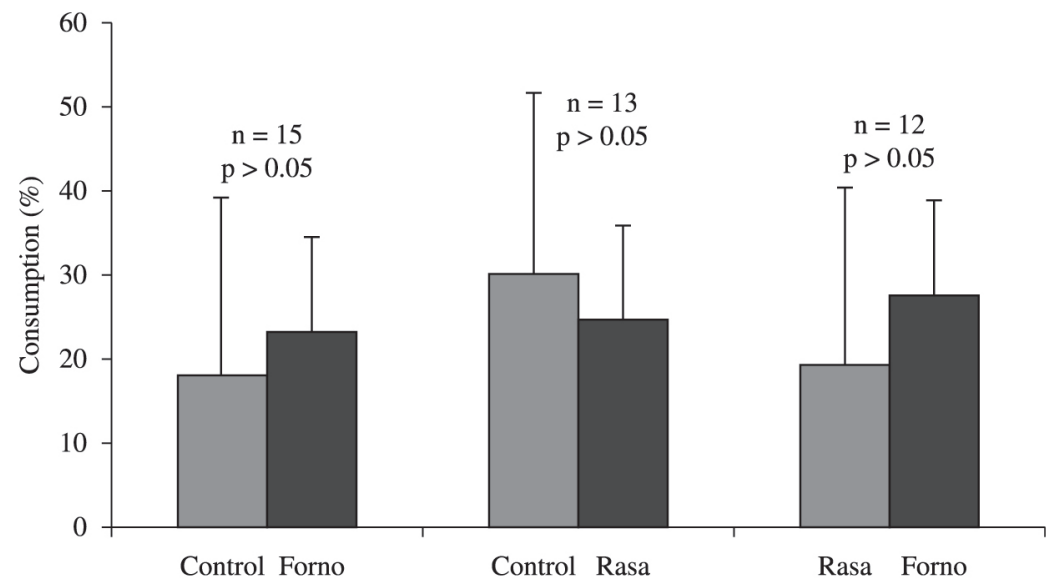

Figure 3. Effect of crude extracts from specimens of $P$. brasiliense collected at Praia Rasa and Forno on the consumption by the crab $A$. scutiformis.

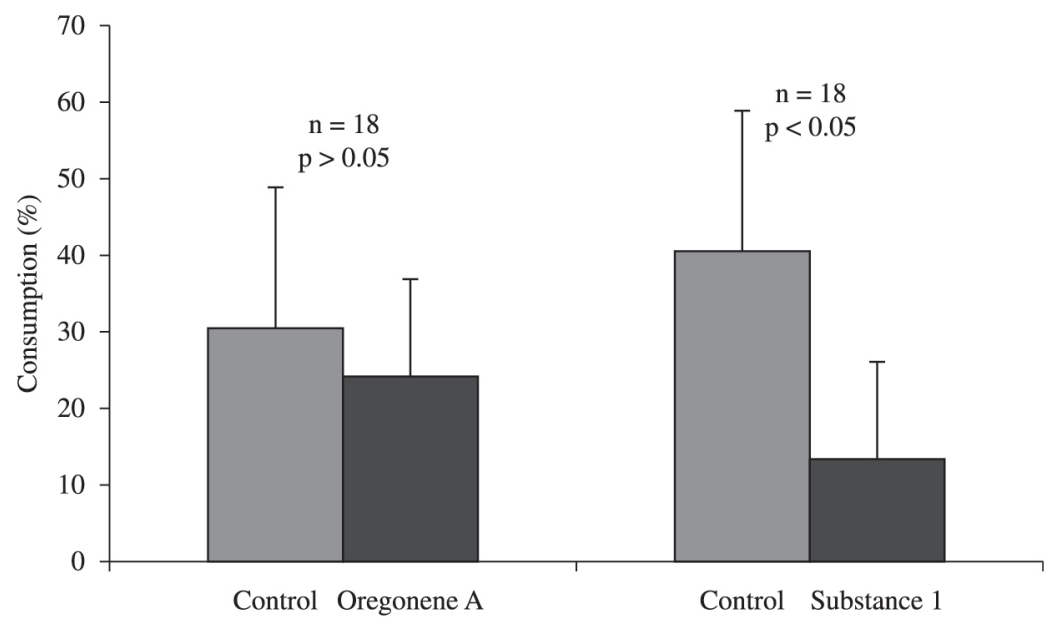

Figure 4. Effect of pure compounds, oregonene and substance 1 from P. brasiliense on the consumption by the sea-urchin L. variegatus. 
lucunter (Linnaeus) and Paracentrotus gaimardii (Blav.) Mortensen are the major invertebrate species (Sabino and Villaça, 1999). All these algal species are known to produce defensive chemicals against consumers (Pereira and Da Gama, 2008), and we could presuppose that they live under high herbivory pressure. On the other hand, Praia Rasa possesses turbid seawater and the most diverse algal flora of Rio de Janeiro state, and the sea-urchin Echinometra lucunter Linnaeus is usually found slightly above algal belts dominated by a dense cover of Sargassum spp. (Yoneshigue-Braga, 1985). However, Sargassum furcatum exhibits low levels of polyphenols, consistent with previous observations from other macroalgae from tropical regions (Targett and Arnold, 1998), and the natural levels of phenols found in this alga did not inhibited herbivory by Parhyale hawaiensis (Pereira and Yoneshigue-Valentin, 1999). According to these environmental characteristics we could presuppose that $P$. brasiliense from Enseada do Forno would be more defended than those specimens of this red alga from Praia Rasa. However, feeding experiments revealed just the opposite result. Thus, it is impossible to affirm that environmental characteristics (abiotic or biotic) would be responsible for the difference in defensive chemicals found in the two populations of $P$. brasiliense studied here. On the other hand, due to a distance of only about $30 \mathrm{Km}$ between Praia Rasa and Enseada do Forno, we could suppose high genetic similarity between specimens of $P$. brasiliense from these two places. However, further genetic studies will be necessary to clarify this question and to explain why populations of a single species living in different but closely located places can exhibit distinct chemicals.

\section{Acknowledgements}

This work was supported with research grants from the Conselho Nacional de Desenvolvimento Científico e Tecnológico $(\mathrm{CNPq})$ and the Fundação de Amparo à Pesquisa do Estado do Rio de Janeiro (FAPERJ). We are grateful to Valéria Laneuville Teixeira and Diana Negrão Cavalcanti for help with identification and quantification of the compounds, and to CNPq for financial support and for Productivity Fellowships to RCP and a Master's degree fellowship to MAV.

\section{References}

AMSLER, CD. (Ed.), 2008. Algal chemical ecology. London: Springer. 313 p. http://dx.doi.org/10.1007/978-3-540-74181-7.

AMSLER, CD., MCCLINTOCK, JB. and BAKER, BJ., 2008. Macroalgal chemical defenses in polar marine communities. In AMSLER, CD. (Ed.). Algal chemical ecology. London: Springer. p. 91-103.

ANKISETTY, S., NANDIRAJU, S., WIN, H., PARK, YC., AMSLER, CD., MCCLINTOCK, JB., BAKER, JA., DIYABALANAGE, TK., PASARIBU, A., SINGH, MP., MAIESE, WM., WALSH, RD., ZAWOROTKO, MJ. and BAKER, BJ., 2004. Chemical investigation of predator-deterred macroalgae from the Antarctic peninsula. Journal of Natural Products, vol. 67, no. 8, p. 12951302. http://dx.doi.org/10.1021/np049965c. PMid:15332845

BARBOSA, JP., TEIXEIRA, VL. and PEREIRA, RC., 2004. A dolabellane diterpene from the brown alga Dictyota pfaffii as chemical defense against herbivores. Botanica Marina, vol. 47, no. 2, p. 147-151. http://dx.doi.org/10.1515/BOT.2004.015.

BLUNT, JW., COPP, BR., KEYZERS, RA., MUNRO, MH. and PRINSEP, MR., 2012. Marine natural products. Natural Product Reports, vol. 29, no. 2, p. 144-222. http://dx.doi.org/10.1039/ c2np00090c. PMid:22193773

BLUNT, JW., COPP, BR., HU, WP., MUNRO, MH., NORTHCOTE, PT. and PRINSEP, MR., 2009. Marine natural products. Natural Product Reports, vol. 26, no. 2, p. 170-244. http://dx.doi.org/10.1039/ b805113p. PMid:19177222

BLUNT, JW., COPP, BR., MUNRO, MHG., NORTHCOTE, PT. and PRINSEP, MR., 2010. Marine natural products. Natural Product Reports, vol. 27, p. 165-237.

BLUNT, JW., COPP, BR., MUNRO, MHG., NORTHCOTE, PT. and PRINSEP, MR., 2011. Marine natural products. Natural Product Reports, vol. 28, p. 196-268.

CAPON, RJ., ENGELHARDT, LM., GHISALBERTI, EL., JEFFERIES, PR., PATRICK, VA. and WHITE, AH., 1984. Structural studies of polyhalogenated monoterpenes from Plocamium species. Australian Journal of Chemistry, vol. 37, no. 3, p. 537-544. http:// dx.doi.org/10.1071/CH9840537.

COLL, JC., SKELTON, BW., WHITE, AH. and WRIGHT, AD., 1988. Tropical marine algae. 2 . The structure determination of new halogenated monoterpense from Plocamium hamatum (Rhodophyta, Gigartinales, Plocamiaceae). Australian Journal of Chemistry, vol. 41, no. 11, p. 1743-1753. http://dx.doi.org/10.1071/CH9881743.

CREWS, P. and KHO-WISEMAN, E., 1977. Acyclic polihalogenated monoterpneses from the red alga Plocamium violaceum. The Journal of Organic Chemistry, vol. 42, p. 2634-2636.

CREWS, P., CAMPBELL, L. and HERON, E., 1977. Different chemical types of Plocamium violaceum (Rhodophyta) from the Monterey Bay region, California. Journal of Phycology, vol. 13, p. 297-301.

CRONIN, G., 2001. Resource allocation in seaweeds and marine invertebrates: chemical defense patterns in relation to defense theories. In MCCLINTOCK, JB. and BAKER, BJ. (Eds.). Marine chemical ecology. Baton Rouge: CRC Press. p. 325-353.

CRONIN, G., PAUL, VJ., HAY, ME. and FENICAL, W., 1997. Are tropical herbivores more resistant than temperate herbivores to seaweed chemical defenses? Diterpenoid metabolites from Dictyota acutiloba as feeding deterrents for tropical versus temperate fishes and urchins. Journal of Chemical Ecology, vol. 23, no. 2, p. 289302. http://dx.doi.org/10.1023/B:JOEC.0000006360.36833.13.

DAVIS, AR., BENKENDORFF., K. and WARD, DW., 2005. Responses of common SE Australian herbivores to three suspected invasive Caulerpa spp. Marine Biology, vol. 146, no. 5, p. 859868. http://dx.doi.org/10.1007/s00227-004-1499-z.

DE NYS, R., COLL, JC. and PRICE, IR., 1991. Chemically mediated interactions between the red alga Plocamium hamatum (Rhodophyta) and the octocoral Sinularia cruciata (Alcyonacea). Marine Biology, vol. 108, no. 2, p. 315-320. http://dx.doi. org/10.1007/BF01344346.

DE NYS, R., DWORJANYN, SA. and STEINBERG, PD., 1998. A new method for determining surface concentrations of marine 
natural products on seaweeds. Marine Ecology Progress Series, vol. 162, p. 79-87. http://dx.doi.org/10.3354/meps 162079.

DE NYS, R., STEINBERG, PD., WILLIEMSEN, P., DWORJANYN, SA., GABELISH, CL. and KING, RJ., 1995. Broad spectrum effects of secondary metabolites from the red alga Delisea pulchra in antifouling assays. Biofouling, vol. 8, no. 4, p. 259-271. http:// dx.doi.org/10.1080/08927019509378279.

FAIRHEAD, VA., AMSLER, CD., MCCLINTOCK, JB. and BAKER, BJ., 2006. Lack of defense or phlorotannins induction by UV radiation or mesograzers in Desmarestia anceps and D. menziesii (Phaeophyceae). Journal of Phycology, vol. 42, no. 6, p. 1174-1183. http://dx.doi.org/10.1111/j.1529-8817.2006.00283.x.

FAULKNER, D., 1977. Interesting aspects of marine natural products chemistry. Tetraherdon, vol. 33, no. 12, p. 1421-1443. http://dx.doi.org/10.1016/0040-4020(77)88001-0.

HARPER, MK., BUGNI, TS., COPP, BR., JAMES, RD., LINDSAY, BS., RICHARDSON, AD., SCHNABEL, PC., TASDEMIR, D., VANWAGONER, RM., VERBITSKI, SM. and IRELAND, CM., 2001. Introduction to the chemical ecology of marine natural products. In MCCLINTOCK, JB. and BAKER, BJ. (Eds.). Marine chemical ecology. CRC Press. p. 3-69.

HAY, ME., 1992. The role of seaweeds chemical defenses in the evolution of feeding specialization and in the mediation of complex interactions. In PAUL, VJ. (Ed.). Ecological roles of marine natural products. Cornell University Press. p. 93-118.

HAY, ME. and FENICAL, W., 1988. Marine plant-herbivore interactions: the ecology of chemical defense. Annual Review of Ecology and Systematics, vol. 19, no. 1, p. 111-145. http://dx.doi. org/10.1146/annurev.es.19.110188.000551.

HAY, ME., KAPPEL, QE. and FENICAL, W., 1994. Synergism in plant defenses against herbivores: interactions of chemistry, calcification, and plant quality. Ecology, vol. 75, no. 6, p. 17141726. http://dx.doi.org/10.2307/1939631.

HAY, ME., DUFFY, JE., PAUL, VJ., RENAUD, PE. and FENICAL, W., 1990. Specialist herbivores reduce their susceptibility to predation by feeding on the chemically-defended seaweed Avrainvillea longicaulis. Limnology and Oceanography, vol. 35, no. 8, p. 1734-1743. http://dx.doi.org/10.4319/1o.1990.35.8.1734.

HIGGS, MD., VANDERAH, DJ. and FAULKNER, DJ., 1977. Polyhalogenated monoterpenes from Plocamium cartilagineum from the British Coast. Tetrahedron, vol. 33, no. 21, p. 2775-2780. http://dx.doi.org/10.1016/0040-4020(77)80267-6.

KONIG, GM., WRIGHT, AD., DE NYS, R. and STICHER, O., 1990. New terpenoid metabolites from marine algae. Planta Medica, vol. 56, no. 6, p. 559-560. http://dx.doi.org/10.1055/s-2006-961144.

LIMA, LMS., ALOR, R., URIOSTEGUI, R., MURRAY, SN. and PEREIRA, RC., 2008. Within-plant variation in palatability and chemical defenses in the green seaweed Avrainvillea elliottii. Botanica Marina, vol. 51, no. 1, p. 21-25. http://dx.doi.org/10.1515/ BOT.2008.001.

MASCHEK, JA. and BAKER, BJ., 2008. The chemistry of algal secondary metabolism. In AMSLER, CD. (Ed.). Algal chemical ecology. London: Springer. p. 1-24.

MYNDERSE, JS. and FAULKNER, DJ., 1978. Variations in the halogenated monoterpene metabolites of Plocamium cartilagineum and Plocamium violaceum. Phytochemistry, vol. 17, no. 2, p. 237-240. http://dx.doi.org/10.1016/S0031-9422(00)94153-0.
NAYLOR, S., HANKE, FJ., MANES, LV. and CREWS, P., 1983. Chemical and biological aspects of marine monoterpenes. Progress in the Chemistry of Organic Natural Products, vol. 44, p. 189-241.

PAUL,VJ., CRUZ-RIVERA, E. and THACKER, RW., 2001. Chemical mediation of macroalgal herbivore interactions: ecological and evolutionary perspectives. In MCCLINTOCK, JB. and BAKER, BJ. (Eds.). Marine chemical ecology. CRC Press. p. 227-265.

PAUL, VJ. and FENICAL, W., 1986. Chemical defense in tropical green algae, order Caulerpales. Marine Ecology Progress Series, vol. 34, p. 157-169. http://dx.doi.org/10.3354/meps034157.

PAUL, VJ. and FENICAL, W., 1987. Natural products chemistry and chemical defense in tropical marine algae of the phylum Chlorophyta. In SCHEUER, PJ. (Ed.). Bioorganic marine chemistry. Springer. p. 1-37. vol. I.

PENNINGS, SC. and PAUL, VJ., 1992. Effect of plant toughness, calcification, and chemistry on herbivory by Dolabella auricularia. Ecology, vol. 73, no. 5, p. 1606-1619. http://dx.doi. org/10.2307/1940014.

PEREIRA, RC. and DA GAMA, BAP., 2008. Macroalgal chemical defenses and their roles in structuring tropical marine communities. In AMSLER, CD. (Ed.). Algal chemical ecology. London: Springer. p. 25-55.

PEREIRA, RC. and YONESHIGUE-VALENTIN, Y., 1999. The role of polyphenols from tropical brown alga Sargassum furcatum on the feeding by amphipod herbivores. Botanica Marina, vol. 42, no. 5, p. 441-448. http://dx.doi.org/10.1515/BOT.1999.051.

PEREIRA, RC., CAVALCANTI, DN. and TEIXEIRA, VL., 2000a. Effects of secondary metabolites from the tropical Brazilian brown alga Dictyota menstrualis on the amphipod Parhyale hawaiensis. Marine Ecology Progress Series, vol. 205, p. 95-100. http://dx.doi. org/10.3354/meps205095.

PEREIRA, RC., DONATO, R., TEIXEIRA, VL. and CAVALCANTI, DN., 2000b. Chemotaxis and chemical defenses in seaweed susceptibility to herbivory. Revista Brasileira de Biologia, vol. 60 , no. 3 , p. 405-414. http://dx.doi.org/10.1590/S003471082000000300005. PMid:11188866

PEREIRA, RC., PINHEIRO, MD., TEIXEIRA, VL. and DA GAMA, BAP., 2002. Feeding preferences of the endemic gastropod Astraea latispina in relation to chemical defenses of Brazilian tropical seaweeds. Revista Brasileira de Biologia = Brazilian Journal of Biology, vol. 62, no. 1, p. 33-40. http://dx.doi.org/10.1590/ S1519-69842002000100005. PMid:12185921

PEREIRA, RC., SOARES, AR., TEIXEIRA, VL., VILLAÇA, R., and GAMA, BAP., 2004. Variation in chemical defenses against herbivory in Southwestern Atlantic Stypopodium zonale (Phaeophyta). Botanica Marina, vol. 47, no. 3, p. 202-208. http:// dx.doi.org/10.1515/BOT.2004.020.

ROVIROSA, J., SANCHEZ, I., PALACIOS, Y., DARIAS, J. and SAN-MARTIN, A., 1990. Antimicrobial activity of a new monoterpene from Plocamium cartilagineum from Antarctica Peninsula. Boletín de la Sociedad Chilena de Química, vol. 35, p. 131-135.

ROVIROSA, J., MOENA, J. and SAN-MARTÍN, A., 1988. Two chemical types of red alga plocamium cartilagineum from Chile. Biochemical Systematics and Ecology, vol. 16, p. 593-595. http:// dx.doi.org/10.1016/0305-1978(88)90068-3

SABINO, CM. and VILLAÇA, RC., 1999. Estudo comparativo de métodos de amostragem de comunidades de Costão. Revista 
Brasileira de Biologia, vol. 59, no. 3, p. 407-419. http://dx.doi. org/10.1590/S0034-71081999000300005.

SAKATA, K., IWASE, Y., INA, K. and FUJITA, D., 2000. Chemical studies on feeding inhibitors for marine herbivores. Part II. Halogenated terpenes isolated from the red alga Plocamium leptophyllum as feeding inhibitors for marine herbivores. Nippon Suisan Gakkai Shi, vol. 57, no. 4, p. 743-746. http://dx.doi. org/10.2331/suisan.57.743.

SAN-MARTIN, A. and ROVIROSA, L., 1986. Variations in the halogenated monoterpenes metabolites of Plocamium cartilagineum of the Chilean Costa. Biochemical Systematics and Ecology, vol. 14, no. 5, p. 459-461. http://dx.doi.org/10.1016/0305-1978(86)90002-5.

SOUZA, CF., OLIVEIRA, AS. and PEREIRA, RC., 2008. Feeding preference of the sea urchin Lytechinus variegatus (Lamarck, 1816) on seaweeds. Brazilian Journal of Oceanography, vol. 56, no. 3, p. 239-247. http://dx.doi.org/10.1590/S1679-87592008000300008.

SUDATTI, DB., FUJII, MT., RODRIGUES, SV., TURRA, A. and PEREIRA, RC., 2011. Effects of abiotic factors on growth and chemical defenses in cultivated clones of Laurencia dendroidea J. Agardh (Ceramiales, Rhodophyta). Marine Biology, vol. 158, no. 7, p. 1439-1446. http://dx.doi.org/10.1007/s00227-011-1660-4.

SUDATTI, DB., RODRIGUES, SV. and PEREIRA, RC., 2006. Quantitative GC-ECD analysis of halogenated metabolites: determination of surface and within-thallus elatol of Laurencia obtusa. Journal of Chemical Ecology, vol. 32, no. 4, p. 835-843. http://dx.doi.org/10.1007/s10886-006-9033-z. PMid:16718572

TARGETT, NM. and ARNOLD, TM., 1998. Predicting the effects of brown algal phlorotannins on marine herbivores in tropical and temperate oceans. Journal of Phycology, vol. 34, no. 2, p. 195-205. http://dx.doi.org/10.1046/j.1529-8817.1998.340195.x.

TOTH, GB. and PAVIA, H., 2006. Artificial wounding decreases plant biomass and shoot strength of the brown seaweed Ascophyllum nodosum (Fucales, Phaeophyceae). Marine Biology, vol. 148, no. 6, p. 1193-1199. http://dx.doi.org/10.1007/s00227-005-0167-2.

VAN ALSTYNE, KL., 1989. Adventitious branching as a herbivore-induced defense in the intertidal brown alga Fucus distichus. Marine Ecology Progress Series, vol. 56, p. 169-176. http://dx.doi.org/10.3354/meps056169.

VASCONCELOS, MA., MENDES, TC., FORTES, WLS. and PEREIRA, RC., 2009. Feeding and decoration preferences of the epialtidae crab Acanthonyx scutiforms. Brazilian Journal of Oceanography, vol. 57, no. 2, p. 137-143. http://dx.doi.org/10.1590/ S1679-87592009000200006.

VASCONCELOS, MA., FERREIRA, WJ., PEREIRA, RC., CAVALCANTI, DN. and TEIXEIRA, VL., 2010. Chemical constituents from the red alga Plocamium brasiliense (Greville) M. Howe and W.R. Taylor. Biochemical Systematics and Ecology, vol. 38, no. 1, p. 119-121. http://dx.doi.org/10.1016/j.bse.2009.12.031.

WYLIE, CR. and PAUL, VJ., 1988. Feeding preferences of the surgeonfish Zebrasoma flavescens in relation to chemical defenses of tropical algae. Marine Ecology Progress Series, vol. 45, p. 23-32. http://dx.doi.org/10.3354/meps045023.

YONESHIGUE-BRAGA, Y., 1985. Taxonomie et ecologie des algues marines dans la re'gion de Cabo Frio (Rio de Janeiro, Brésil). França: Universite' d'Aix-Marseille. 466 p. vol. II. Tese de Doutorado em Ecologia. 